\title{
UMA AFRONTA À DIGNIDADE PSICOLÓGICA DO TRABALHADOR
}

AN ADJUSTMENT TO THE PSYCHOLOGICAL DIGNITY OF THE

WORKER

\section{CAMILA MUSETI BEZERRA ${ }^{1}$}

ISSUE DOI: $10.21207 / 1983.4225 .475$

\section{RESUMO}

O presente artigo abordará o tema Assédio Moral nas relações de emprego e as consequências, principalmente psicológicas, que determinada prática pode acarretar ao assediado. $\mathrm{O}$ assédio moral é tido como um ilícito civil, que gera para o agressor a responsabilidade de indenizar a vítima pelos danos sofridos. Os danos podem ser das mais variadas espécies, sendo que o dano psicológico, via de regra, ocorre, porém não é elemento fundamental para caracterizar tal ato ilícito, mas sim é tido como consequência da conduta ilícita. Com o assédio moral, o agressor fere diversos princípios constitucionais e ataca o valor supremo da Constituição Federal de 1.988, que é o Princípio da Dignidade da Pessoa Humana, que contém inserido em seu bojo, todos os demais princípios.

Palavras-chave: Assédio moral. Relações de emprego. Ato ilícito. Responsabilidade. Indenização. Princípios constitucionais.

\footnotetext{
${ }^{1}$ Graduada em Direito pela Faculdade de Direito de Franca. Pós-graduanda em Direito do Trabalho pela Universidade Anhanguera-Uniderp. Advogada. Professora de Direito do Trabalho para exames da OAB nos Cursos Márcio Cunha.
} 


\section{ABSTRACT}

This article will address the theme Moral Harassment in employment relationships and consequences, mainly psychological, that particular practice can lead to beleaguered. Bullying is seen as a civil offense, which generates to the aggressor responsibility to compensate the victim for damages. Damage can be the most varied species, and the psychological damage usually occurs, but it is not fundamental element to characterize such unlawful act, but as a result of unlawful conduct. With bullying, the aggressor injures several constitutional principles and attacks the supreme value of the Constitution of 1988, which is the principle of human dignity, which contains inserted within itself all the other principles.

Keywords: Bullying. Labor relations. Tort. Responsibility. Indemnity. Constitutional principles.

\section{INTRODUÇÃO}

O presente artigo tem como foco o assédio moral nas relações de emprego como forma de degradação à saúde psíquica do trabalhador. Serão abordadas as linhas gerais caracterizadoras desse tipo de conduta e quais as consequências nocivas ao empregado, sujeito a ser analisado, que possui vínculo empregatício com determinado empregador.

Apesar de vários estudos sobre o tema, o presente artigo mostrase contemporâneo, face à crescente prática no âmbito das relações empregatícias, devido à globalização desenfreada que norteia o século XXI.

Outro aspecto curioso que embasa o assédio moral são as questões que envolvem discussões acerca de caráter no sentido personalíssimo do ser humano, evidenciando que este, em ambientes que envolvam dinheiro, status, concorrência, pode possuir vertentes escusas, que os faz deixar de lado princípios morais e éticos para destruir aquele que de alguma forma o incomoda ou possa vir a incomodá-lo.

$\mathrm{O}$ assédio moral se apresenta como uma forma de terror psicológico capaz de fazer com que a pessoa a qual se dirige a conduta vá passando por estágios crescentes de destruição psíquica. Ele promove certa forma de exclusão dessa determinada pessoa, e isso afeta não só as regras atinentes ao Direito do Trabalho como normas e princípios constitucionalmente garantidos. 
Necessário se faz diferenciar o assédio moral do assédio sexual, institutos que se distanciam face às peculiaridades de cada um. $\mathrm{O}$ assédio sexual possui previsão expressa no Código Penal, tratando como crime a conduta de cunho sexual do superior hierárquico para com o subalterno. Já o assédio moral não é calcado em atitudes de cunho sexual, mas sim de cunho psicológico, não sendo classificado como crime tipificado em lei.

Depois de feita a diferenciação entre tais institutos, passar-se-á a tratar especificamente do assédio moral. Será dado o conceito geral e suas especificações para as relações de emprego; haverá a descrição dos elementos caracterizadores e ressaltar-se-á a responsabilidade civil pelos danos causados ao empregado, procurando não se deixar de lado o preceito fundamental da dignidade da pessoa humana, tão ferido com as condutas consideradas como assediosas.

Ressalta-se por fim, que o assédio moral será analisado no contexto das relações de emprego, sendo estas vistas sob a ótica da Consolidação das Leis do Trabalho (CLT) e dos seus requisitos, especificamente no local da prestação dos serviços e durante a jornada de trabalho.

\subsection{EVOLUÇÃO TEMPORAL}

O assédio moral não é fenômeno novo. É tão antigo quanto o fenômeno trabalho. Restou configurado inicialmente em países como Inglaterra, Estados Unidos, Alemanha, Suécia, Austrália, etc. À sua crescente prática pode se atribuir ao avanço tecnológico cada vez mais desenfreado e à difusão das ideias capitalistas pelo mundo.

Teve seus primeiros contornos no âmbito das indústrias têxteis, no cenário da Revolução Industrial ocorrida na Inglaterra no século XVIII e XIX. Foi nesse contexto, de transição da economia de manufatura para a mecanização dos sistemas de produção, que a noção de trabalho subordinado se desenvolveu.

Neste diapasão, o Direito do Trabalho ganhou forças, sendo um modo de proteção dos trabalhadores contra os abusos incessantes praticados no interior das indústrias da época. 
Luis Marcelo Figueiras de Góis afirma:

A partir de então, passou-se a limitar a quantidade máxima de trabalho para que os indivíduos pudessem trabalhar mais saudavelmente. $\mathrm{O}$ repouso semanal remunerado e as férias passaram a ser, também, instrumento de combate à estafa e de proteção à higidez física e psicológica. Gestantes e menores começaram a sofrer tratamento privilegiado. $^{2}$

Já século XX, notou-se a adoção de medidas mais eficazes de proteção aos trabalhadores, proporcionando-lhes o mínimo de dignidade no ambiente de produção. Assim desenvolveram-se algumas medidas assecuratórias da profissão e consequentemente, da remuneração.

No anseio por lucratividade e produtividade, os ambientes de trabalho estavam se tornando cada vez mais competitivos, como se já não bastasse a competição externa verificada. Começa, portanto, a caracterização do assédio moral.

Candy Florêncio Thomé diz que "casos de constrangimento moral foram julgados na Justiça desde a década de 60 "3, evidenciando que o fenômeno não é novo e resta configurado mais e mais nas relações de emprego.

$\mathrm{Na}$ busca pela produtividade, estabilidade empregatícia, reconhecimento no mercado de trabalho, muitas pessoas colocaram em sua mente a ideia de acabar a qualquer custo com aqueles que "atravessem seu caminho" e possam de alguma maneira prejudicar seus objetivos. Dentro do cenário capitalista e globalizado, no qual o trabalho deixou de ser simples para tornar-se complexo e especializado, foi que o assédio moral ganhou força.

Porém, foi dentro dos campos da psiquiatria e da psicologia que o assédio moral ganhou a caracterização que recebe nos dias de hoje, na qual o direito do trabalho importou para o seu campo de atuação, por ser a

\footnotetext{
${ }^{2}$ GÓIS, Luiz Marcelo Figueiras de. Assédio moral: a nova ameaça à integridade do ambiente de trabalho. Revista IOB Trabalhista e Previdenciária. n. 243, p.88, set./09.

3 THOME, Candy Florencio. O assédio moral nas relações de emprego. São Paulo: LTr, 2008. p. 24.
} 
seara em que o fenômeno mais se desenvolve e onde se encontram as práticas mais corriqueiras.

Estudos como o do psiquiatra alemão Heinz Leymann, realizados por volta dos anos 80, descreveram e analisaram os distintos comportamentos que se delineavam dentro do âmbito trabalhista, percebendo com crescente frequência a ocorrência de comportamentos hostis durante a jornada de trabalho. ${ }^{4}$

Através dos contornos que o assédio moral foi adquirindo e por sua prática cada vez mais frequente, a Organização Internacional do Trabalho (OIT), criada em 1919, estabeleceu regras de proteção ao ambiente do trabalho, como mais um instrumento a favor de proteger pessoas agredidas com condutas ilícitas.

Deve-se ressaltar também, que além dos fatores econômicos que influenciaram o assédio moral e sua caracterização, laços culturais também o fazem, principalmente quanto à forma com que ele será praticado no ambiente de trabalho.

André Luiz Souza Aguiar afirma que:

Os traços típicos e característicos da cultura brasileira não estão distantes do cotidiano organizacional: o estilo paternalista e autoritário de administrar foi gerado no engenho, na casa grande e na senzala, fortalecido pelo coronelismo $\mathrm{e}$ solidificado pela gerência empresarial. ${ }^{5}$

Um dos trabalhos pioneiros sobre o assunto foi o da jornalista inglesa Andréa Adams que, em 1995, denunciou, em seu livro, o assédio moral como uma forma de psicoterrorismo. ${ }^{6}$

Assim, observa-se que, cada país com sua cultura e costumes, pode caracterizar um modo peculiar de cometimento do assédio moral,

\footnotetext{
4 PEDUZZI, Maria Cristina Irigoyen. Assédio moral. Revista do Tribunal Superior do Trabalho. Rio de Janeiro, n. 2, v. 73, p.25, abr./jun. 2007.

5 AGUIAR, André Luiz Souza. Assédio moral: o direito à indenização pelos maus tratos e humilhações sofridos no ambiente de trabalho. São Paulo: LTr, 2005. p. 61.

${ }^{6}$ OLIVEIRA, Euler Sinoir de. Assédio moral: sujeitos, danos à saúde e legislação. Disponível em: <http://psicologiaetrabalho.blogspot.com/2007/08/assdio-moral-sujeitosdanos-sade-e.html>. Acesso em 9 mai. 2016.
} 
sem perder a sua estrutura básica que é a degradação do psicológico do empregado.

\section{ASSÉDIO SEXUAL, ASSÉDIO MORAL E A RELAÇÃO DE EMPREGO}

\subsection{CONCEITOS DE ASSÉDIO MORAL E ASSÉDIO SEXUAL}

Assédio sexual e assédio moral são espécies do gênero assédio. Por assédio em geral pode-se entender que são todas as condutas capazes de causar uma violência física, psíquica ou sexual à pessoa.

O Assédio Sexual caracteriza-se através de condutas de caráter sexual, reiteradas ou não e ligadas ao ambiente laborativo. Através de tal comportamento, o agressor "tem por fim constranger a pessoa em sua intimidade e privacidade". 7

O artigo 216-A do Código Penal (CP) caracteriza o assédio sexual como crime e assim o define: "Constranger alguém com o intuito de obter vantagem ou favorecimento sexual, prevalecendo-se o agente de sua condição de superior hierárquico ou ascendência inerentes a exercício de emprego, cargo ou função".

Por sua vez, o Assédio Moral, também conhecido também como mobbing, bullying, harcèlemente, pode ser conceituado como atitudes de natureza psicológica, que praticadas de forma reiteradas e prolongadas por superior hierárquico ou mesmo colegas de trabalho, expõem o assediado a situações humilhantes, vexatórias, capazes de diminuí-lo como pessoa e que atentam contra sua integridade física, psicológica, contra sua personalidade e dignidade.

Marie-France Hirigoyen explica que:

As agressões, no assédio moral, são fruto de um processo inconsciente de destruição psicológica,

\footnotetext{
${ }^{7}$ NASCIMENTO, Sônia Maria Mascaro. O assédio moral no ambiente do trabalho. <http://jus2.uol.com.br/doutrina/texto.asp?id=5433>. Acesso em: 9 mai. 2016.
} 
constituindo-se, tal processo, de atos hostis mascarados ou implícitos, de um ou de vários indivíduos sobre um indivíduo específico, por meio de palavras, alusões, sugestões de "não ditos"(...) Trata-se de um processo real de destruição moral, que pode conduzir à doença mental ou ao suicídio. ${ }^{8}$

O Tribunal Regional do Trabalho da $15^{\text {a }}$ Região, seguindo a linha da psiquiatra acima citada, posicionou-se da seguinte forma:

\begin{abstract}
EMENTA. INDENIZAÇÃO - ASSÉDIO MORAL NO TRABALHO - OFENSA À HONRA, À IMAGEM E À DIGNIDADE DO TRABALHADOR. O assédio moral no trabalho, segundo Marie-France Hirigoeyen, é "toda e qualquer conduta abusiva manifestando-se sobretudo por comportamentos, palavras, atos, gestos, escritos que possam trazer dano à personalidade, à dignidade ou à integridade física ou psíquica de uma pessoa, por em perigo seu emprego ou degradar o ambiente de trabalho. ${ }^{9}$
\end{abstract}

Assim, tem-se que o assédio moral é uma prática que visa à degradação da estrutura psicológica do assediado, geralmente o empregado, minando com sua autoestima, confiança e, por conseguinte, com sua capacidade laborativa, face ao terror psicológico sofrido, tornando o agredido improdutivo dentro do ambiente de trabalho. Além do mais é capaz de desencadear uma série de doenças ligadas à estrutura emocional, mostrando a gravidade das condutas e a seriedade com que se deve encará-lo.

\footnotetext{
${ }^{8}$ HIRIGOYEN, Marie-France. Le harcèlement moral: la violence perverse du quotidian. Paris: Editions Le Livre de Ponche, 2000. p. 9-15.

${ }^{9}$ BRASIL. Tribunal Regional do Trabalho da $15^{\text {a }}$ Região. Indenização. Matéria Trabalhista. Assédio Moral. ofensa à honra, à imagem e à dignidade do trabalhador. Decisão $\mathrm{n}^{\circ}$ 027971/2010.Relator: José Antonio Pancotti. Disponível em: <http://consulta.trt15.jus.br/consulta/owa/wPesquisaJurisprudencia>. Acesso em: $16 / 06 / 2016$.
} 


\subsubsection{Diferenças básicas entre assédio moral e assédio sexual}

O assédio sexual e o assédio moral são duas figuras distintas para o direito, cada um com as próprias peculiaridades, características e efeitos. Assemelham-se em alguns fatos como, por exemplo: os dois tipos caracterizam-se por ações repetidas, o agente tanto pode ser homem, quanto mulher, que podem ser ligados pelas relações de âmbito trabalhista.

Mas através do que se pode extrair do conceito dessas duas espécies de assédio verifica-se que eles divergem em muitos pontos, sendo o principal deles quanto à natureza da conduta, ou seja, o assédio sexual possui condutas de cunho sexual, sendo que em contrapartida, o assédio moral apresenta condutas de natureza psicológica. Alem do mais, no assédio sexual o intuito não é destruir psicologicamente a vítima, mas sim obter dela favores ou vantagens sexuais.

Distanciam-se ainda pelo fato de o assédio sexual ser considerado crime, com expressa previsão no Código Penal, enquanto o assédio moral não. Em virtude disso, possuem regramento repressivo que também se distanciam, pois o assédio moral será regulado através do instituto da responsabilidade civil, elucidado no Direito Privado, enquanto o assédio sexual, pela Responsabilidade Penal, de aspecto público.

Por isso, não podem ser confundidos, pois cada uma dessas figuras possuem elementos caracterizadores próprios, que os tornam particulares. Mas, mesmo com todas as diferenças permeadas entre si, são práticas que causam asco na sociedade e devem ser veementemente combatidas.

\subsection{DA RELAÇÃO DE TRABALHO E RELAÇÃO DE EMPREGO}

É necessário esclarecer que nas relações de emprego, o assédio moral se exterioriza com maior facilidade do que nas relações de trabalho, ante a existência do poder diretivo que o empregador exerce sobre seus empregados, entendendo que esse, em vários momentos e situações é absoluto e em contrapartida o empregado, subordinado a tal poder, sujeita-se à práticas degradantes, humilhantes, tendo em vista a necessidade da 
manutenção do emprego. Nas relações de trabalho, as condutas assediosas são mais restritas em virtude da autonomia do prestador de serviços e até mesmo da pluralidade de tomadores de serviços, visto que o prestador consegue se impor nessa relação estabelecida entre as partes.

Portanto, torna-se pertinente a abordagem dos conceitos de relação de trabalho e de emprego, pois o assédio moral será discutido sob o enfoque e contexto desse último.

Por relação de trabalho entende-se a atividade que é exercida sem que estejam presentes de forma cumulativa os requisitos constantes no final do artigo $2^{\circ}$ e no $3^{\circ}$ da CLT. Deve-se entender que relação de trabalho é um gênero do qual a relação de emprego é espécie.

José Cairo Júnior expõe que:

A relação de trabalho constitui gênero da prestação de serviços, do qual se originam várias espécies. Sempre que o trabalho for prestado por uma pessoa em proveito de outra, sendo esse trabalho de meio ou de resultado, haverá uma relação de trabalho lato sensu. ${ }^{10}$

Assim, observa-se que existem vários tipos especiais de trabalho que caracterizam e exemplificam a relação de trabalho, aos quais se podem citar, o trabalho autônomo, o avulso, o eventual, etc.

Já a relação de emprego é algo bem mais formal e, para se caracterizar, é necessário que alguns requisitos sejam preenchidos. Tais requisitos encontram-se presentes já na parte final do art. $2^{\circ}$, da CLT c.c art. $3^{\circ}$ da CLT. São eles: pessoa física, subordinação, habitualidade (não eventualidade), onerosidade e pessoalidade. O autor Sérgio Pinto Martins elenca outro requisito, ao qual dá o nome de alteridade.

Para haver uma relação típica de emprego, todos esses requisitos acima mencionados devem estar presentes cumulativamente. A falta de qualquer um deles desnatura a relação.

Com isso, pode entender que relação de emprego é aquela em que o empregado, pessoa física, realiza suas atividades no âmbito laboral de forma pessoal e não eventual, estando sujeito aos comandos do empre-

${ }^{10}$ CAIRO JÚNIOR. José. Curso de direito do trabalho: direito individual e coletivo do trabalho. 3.ed. Salvador: Jus Podivm, 2009. p. 126. 
gador, pessoa física ou jurídica, sendo subordinado a ele e recebendo contraprestação onerosa pelo serviço realizado.

\subsection{DOS ELEMENTOS DA RELAÇÃO DE EMPREGO}

\subsubsection{Requisitos}

Os requisitos para a configuração da relação de emprego encontram-se acostados no final do artigo $2^{\circ}$, da CLT e art. $3^{\circ}$ da CLT, sendo eles: subordinação, habitualidade, onerosidade, pessoalidade e até um quinto elemento chamado alteridade, sendo o trabalhador sempre uma pessoa física.

\subsubsection{Da subordinação}

A subordinação se funda em uma relação de comando/obediência, na qual quem detém tal comando dá as ordens e o subordinado as executa. Tal subordinação vem descrita no contrato de trabalho.

\subsubsection{Da habitualidade (não eventualidade)}

Pelo requisito da habitualidade, entende-se que o trabalho a ser realizado pelo empregado deve ocorrer de forma não eventual, com caráter de rotina, em que forma-se um hábito e expectativa concreta de serviço. Prega-se a ideia de permanência, mesmo que por curto espaço de tempo.

\subsubsection{Da onerosidade}

Por onerosidade entende-se a contraprestação que o empregador paga ao empregado pela execução dos serviços. Externa-se, geralmente, sob a forma de salário, porém pode haver outras formas, como a remune- 
ração, parte do pagamento em salário in natura. Porém, deve-se ter em mente que primeiro o empregado trabalha, depois o empregador o paga, dentro do prazo estabelecido por Lei.

\subsubsection{Da pessoalidade}

Na pessoalidade evidencia-se que o contrato de trabalho é intuito personae, ou seja, o serviço deve ser realizado, por pessoa certa e determinada, não sendo permitido ao empregado fazer-se substituir por outra pessoa, a não ser nos casos estritamente permitidos por lei.

\subsubsection{Da alteridade}

A alteridade não é requisito unânime entre os doutrinadores para a configuração da relação de emprego. Ele é trazido por alguns autores que partem de uma interpretação sistemática e teleológica para sua construção.

Por alteridade, pode-se entender como o serviço prestado à conta de outrem. É o empregador que sofrerá os riscos da prestação do serviço, da atividade econômica, e não o empregado.

Sérgio Pinto Martins, principal construtor da ideia, explica que “o empregado presta serviços por conta alheia (alteridade). É um trabalho sem assunção de qualquer risco pelo trabalhador (...). É requisito do contrato de trabalho o empregado prestar serviços por conta alheia e não por conta própria". ${ }^{11}$

\section{O ASSÉDIO MORAL}

\subsection{O ASSÉDIO MORAL NAS RELAÇÕES DE EMPREGO}

${ }^{11}$ MARTINS. Sérgio Pinto. Direito do trabalho. 24. ed. São Paulo: Atlas, 2008. p. 91 92. 
$\mathrm{O}$ assédio moral não é fenômeno recente e muito menos adstrito ao Brasil, porém passou a ser muito mais observado a partir da década de 80. Muitos países como Alemanha, Argentina, Bélgica possuem legislação específica para puni-lo, mas o Brasil apenas se contentou em considerá-lo como ato ilícito.

Conforme já salientado anteriormente, o assédio moral, também conhecido como mobbing, bulliyng, terror psicológico, é considerado como toda conduta abusiva, permanente e repetitiva, que cause agressões de cunho psicológico, atentando contra a dignidade psíquica da pessoa agredida.

No artigo "E o que é assédio moral no trabalho?" apontam-se algumas considerações sobre o assunto, as quais são:

É a exposição dos trabalhadores e trabalhadoras a situações humilhantes e constrangedoras, repetitivas e prolongadas durante a jornada de trabalho e no exercício de suas funções (...) em que predominam condutas negativas, relações desumanas e aéticas de longa duração, de um ou mais chefes dirigida a um ou mais subordinado(s), desestabilizando a relação da vítima com o ambiente de trabalho e a organização, forçando-o a desistir do emprego. ${ }^{12}$

Explica também Rodolfo Pamplona Filho que "o assédio moral é toda conduta abusiva, de natureza psicológica, que atenta contra a dignidade psíquica do indivíduo, de forma reiterada, tendo como efeito a sensação de exclusão do ambiente e do convívio social". ${ }^{13}$

Ainda na linha do citado autor, tem-se que:

$\mathrm{Na}$ relação de trabalho subordinado, porém, este "cerco" recebe tons mais dramáticos, por força da própria hipossuficiência de um dos seus sujeitos, em

12 Assédio moral no trabalho: e o que é assédio moral no trabalho? Disponível em: <http://www.assediomoral.org/spip.php?article1>. Acesso em: 16 mai. 2016.

${ }^{13}$ PAMPLONA FILHO, Rodolfo. Noções conceituais sobre assédio moral nas relações de emprego. Disponível em: <www.anamatra.org.br/opiniao/artigos/ler_artigos.cfm?cod_conteudo+7987\&descriçao= Artigos>. Acesso em: 13 mai. 2016. 
que a possibilidade de perda do posto de trabalho que lhe dá subsistência faz com que o empregado acabe se submetendo aos mais terríveis caprichos desvarios, não somente de seu empregador, mas até mesmo de seus próprios colegas de trabalho. ${ }^{14}$

Tem-se que com o terror psicólogo sofrido, o empregado (objeto desta análise) passa a excluir-se e sentir-se menosprezado no ambiente de trabalho, convivendo cada vez menos com as pessoas que integram o ambiente laborativo. Torna-se uma pessoa introspectiva, insegura, sem autoestima, frágil e acima de tudo, improdutiva.

Convém ressaltar que a forma de agir do agressor varia de acordo com o meio de trabalho envolvido. Nos setores de produção ou industriais, as agressões são mais diretas e incisivas. Em contrapartida, se o local de trabalho configura atividades mais clássicas, modernas, o assédio moral de sobressai de forma mais sutil e sofisticada, porém, não deixando de ser assédio, mostrando-se apenas sob uma nova roupagem.

Mas, em qualquer que seja o ambiente de trabalho, as principais formas com que o assédio moral se exterioriza são:

Gestos, condutas abusivas e constrangedoras, humilhar repetidamente, inferiorizar, amedrontar, menosprezar ou desprezar, ironizar, difamar, ridicularizar, risinhos, suspiros, piadas jocosas relacionadas ao sexo, ser indiferente à presença do/a outro/a, estigmatizar os/as adoecidos/as pelo e para o trabalho, colocá-los/as em situações vexatórias, falar baixinho acerca da pessoa, olhar e não ver ou ignorar sua presença, rir daquele/a que apresenta dificuldades, não cumprimentar, sugerir que peçam demissão, dar tarefas sem sentido ou que jamais serão utilizadas ou mesmo irão para o lixo, dar tarefas através de terceiros ou colocar em sua mesa sem avisar, controlar o tempo de idas ao banheiro, tornar público algo íntimo do/a subordinado/a, não

\footnotetext{
${ }^{14}$ PAMPLONA FILHO, Rodolfo. Noç̃̃es conceituais sobre assédio moral nas relações de emprego. Disponível em: <www.anamatra.org.br/opiniao/artigos/ler_artigos.cfm?cod_conteudo+7987\&descriçao= Artigos>. Acesso em: 13 mai. 2016.
} 
explicar a causa da perseguição, difamar,
ridicularizar. ${ }^{15}$

Com isso, nota-se que o assédio moral é uma prática que elimina o sadio ambiente de trabalho, tornando-o tenso, pesado, insuportável para aqueles que sofrem com sua prática. Demonstra uma verdadeira estratégia profissional para fazer com que aquele empregado que não serve mais à empresa ou incomoda seus colegas ou superiores, desista do emprego.

Além do mais, após a reiteração do assédio moral, a vítima fica propensa a desenvolver vários tipos de doenças decorrentes da estafa psicológica que sofreu, tais como: estresse pós-tráumático, síndrome de burn-out, depressão, distúrbios cardíacos, endócrinos, digestivos, gastrite nervosa, alcoolismo, etc, das quais algumas são equiparadas a acidente de trabalho.

O assédio moral, face à sua gravidade, tornou-se assunto constante nos mais variados meios de comunicação, relatando na ficção o que acontece no cotidiano empregatício. Um famoso exemplo de assédio moral nas relações de emprego pode ser encontrado no filme "O Diabo Veste Prada" (The Devil Wears Prada-EUA, 2006). ${ }^{16}$ No filme, aquela secretária "feia", que não se encaixava nos padrões de beleza do mundo fashion, sofria todos os tipos de humilhações dos colegas de trabalho bem como de sua superior hierárquica, pelo simples fato de ser diferente ou ainda só para ver até aonde os seus limites pessoal, emocional e psicológico poderiam chegar.

A escritora Márcia Novaes Guedes considera o assédio moral no trabalho como:

Todos aqueles atos e comportamentos provindos do patrão, gerente ou superior hierárquico ou dos colegas, que traduzem uma atitude de contínua e ostensiva perseguição que possa acarretar danos

\footnotetext{
${ }^{15}$ Assédio Moral no Trabalho. Disponível em: <http://www.assediomoral.org/>. Acesso em 23 mai. 2016.

${ }^{16}$ Ideia retirada do filme “O Diabo Veste Prada” (The Devil Wears Prada, EUA,2006).
} 
relevantes às condições físicas, psíquicas, morais e existenciais da vítima. ${ }^{17}$

Em um de seus julgados, o Tribunal Superior do Trabalho (TST), manifestou-se no seguinte sentido:

Era costume da reclamada que os vendedores que não atingissem as metas propostas, pagassem "prendas" em praça pública, fazendo flexões, corridas, usando capacetes morcegos. Esta prática foi amplamente comprovada pela prova oral e pelas fotos de f. 20/21. Por outro lado, os depoimentos coligidos demonstram que a "brincadeira" não era bem aceita pelos empregados (f. 431). Agindo assim, a reclamada pretendia pressionar o empregado a produzir mais, instigando-o psicologicamente. Embora "aparentemente" saudáveis ou brincalhonas, tais técnicas ferem a dignidade do empregado, quando impostas como "prendas" a serem pagas pelo mal desempenho no trabalho, conduzindo ao desgaste emocional e à auto-depreciação, minando, por óbvio, o seu entusiasmo e a sua vibração com o trabalho, representando verdadeiro assédio moral. Processo: AIRR - 81040-88.2004.5.03.0055 Data de Julgamento: 19/05/2010, Relatora Ministra: Kátia Magalhães Arruda, 5 $5^{\text {a }}$ Turma, Data de Divulgação: DEJT 28/05/2010. ${ }^{18}$

Percebe-se que as atitudes que deflagram o assédio moral no âmbito laboral são provenientes dos patrões, superiores hierárquicos, dos que detêm poder diretivo ou até mesmo dos próprios colegas de trabalho. Tais pessoas praticam a conduta assediosa com o intuito de humilhar, ferir, massacrar e até mesmo pressionar a vítima, no caso um determinado

17 GUEDES, Márcia Novaes. Terror psicológico no trabalho. 2.ed. São Paulo: LTr, 2005. p. 32.

18 BRASIL. Tribunal Superior do Trabalho. Agravo de Instrumento em Recurso de Revista. Matéria Trabalhista. AIRR $\mathrm{n}^{\circ}$ 81040-88.2004.5.03.0055. Relatora Ministra: Kátia Magalhães Arruda. Data de Julgamento: 19/05/2010. Disponível em: <https://aplicacao.tst.jus.br/consultaunificada2/>. Acesso em: 30 mai. 2016. 
empregado, para que este tenha comportamentos que serão convenientes aos intuitos do outro, àquele que pratica a conduta.

\subsection{CLASSIFICAÇÃO}

O assédio moral nasce em diversos tipos de estrutura. Pode ser classificado em quatro distintas formas, conforme o sujeito ativo e a posição que ocupa perante o sujeito passivo. São elas: a-) assédio moral descendente ou vertical; b-)assédio moral horizontal; c-)assédio moral misto; d-) assédio moral ascendente.

$\mathrm{Na}$ vertical ou descendente, as condutas partem do superior hierárquico para o seu subalterno. $\mathrm{O}$ superior abusa consideravelmente do seu poder diretivo disciplinar, aterrorizando e amedrontando o empregado.

Quando é um colega de trabalho que inicia na prática do assédio moral, tem-se um fenômeno no sentido horizontal, sem hierarquia e subordinação. As condutas, geralmente, são motivadas por sentimentos de inveja, raiva, inimizade e até vingança.

Há também o tipo misto, em que as condutas são realizadas por superior hierárquico e colegas de mesmo nível de trabalho. E por fim, existe um tipo menos comum, tido como antinatural, chamado de assédio moral ascendente, no qual empregados de nível inferior ao da vítima, o agridem psicologicamente, ou seja, os subalternos assediam seus superiores hierárquicos, o que não nos interessa muito.

Mas, em quaisquer dos casos, tem-se a certeza que o assédio moral atenta veemente contra a dignidade física, moral e humana da vítima, desrespeitando os direitos da personalidade inerentes a cada indivíduo, desrespeitando preceitos e direitos constitucionalmente garantidos.

\subsection{NATUREZA JURÍDICA}

A teoria do assédio moral possui assento no Princípio da Dignidade da Pessoa Humana, estando este como o valor supremo da Constituição Federal de 1.988 , previsto no art. $1^{\circ}$, inciso III, da Magna Carta. Decorre também do direito fundamental à saúde, mais especificadamente 
à saúde mental, dos direitos da personalidade e dos preceitos de segurança e saúde do trabalhador, todos estes normas de ordem pública e de observância obrigatória.

O assédio moral possui natureza de ilícito civil aplicado em sede trabalhista, gerando como consequência o dever de reparar o dano causado, por aplicação subsidiária autorizada pelos artigos $8^{\circ}$ parágrafo único e 769, ambos da CLT, sendo tal reparação de natureza extrapatrimonial, desde que apurada a responsabilidade do agressor.

A indenização não possui mero aspecto patrimonial e sim um sustentáculo com vertente também educacional, pedagógica, além de reparatória. Isso tudo com o intuito de minimizar os danos psicológicos sofridos pelo empregado e coibir a prática de novos atos.

\subsection{ELEMENTOS DO ASSÉDIO MORAL}

\subsubsection{Natureza psicológica}

Através das condutas vexatórias, que expõem ao ridículo, humilham, massacram o sujeito passivo, nasce a degradação psicológica. Estas ocorrem aos poucos, conforme as condutas vão se repetindo no dia após dia. Muitas vezes são até quase imperceptíveis, mas quando a vítima se dá conta, os danos tomaram uma enorme proporção.

$\mathrm{O}$ assédio moral mexe diretamente com o íntimo da pessoa, desestruturando-a lentamente e acabando com o equilíbrio físico-psiquíco que tal pessoa possuía. A intenção do agente não é simplesmente agredir de forma física a sua vítima, mas sim feri-la de um modo muito mais profundo e de difícil recuperação.

$\mathrm{O}$ agressor procura afetar diretamente a psique do agredido, porque sabe que agindo nessa linha, fragiliza a pessoa e a deixa vulnerável. Consequentemente irá conseguir o que deseja com mais facilidade.

Por isso, o assédio moral necessita do fator psicológico para surtir seus nefastos propósitos. Por sua natureza psicológica, os danos não se revelam de uma hora para outra, sendo isto até conveniente para o sujeito ativo, que pode insistir na conduta, até porque os seus rastros não ficam à mostra ou em evidência. 


\subsubsection{Conduta repetitiva e prolongada}

Característica indispensável à configuração do assédio moral é a repetição da conduta abusiva e dolosa. A conduta não pode ser esporádica, devendo ser reiterada pelo agressor àquela dirigida vítima. É uma conduta que vai se arrastando ao longo do tempo.

Renato da Costa Lino de Goes Barros diz que "há, ainda, a necessidade de esta conduta seja prolongada e reiterada no tempo, afinal, por ser um fenômeno de natureza psicológica não há de ser um ato isolado ou esporádico capaz de trazer lesões psíquicas decorrentes do assédio moral à vítima". ${ }^{19}$

A repetição das condutas de assédio é que causará os danos psicológicos ao sujeito passivo (empregado), pois tal repetição irá, pouco a pouco, fragilizá-lo, deixando-o mais suscetível aos anseios do sujeito ativo, seja ele quem for.

Assim, durante um período de tempo, a conduta deve ser reiterada como já dito, para que seja capaz de agredir a saúde emocional da vítima, formando uma cadeia de sucessivos eventos danosos e com consequências que variam de intensidade ao longo do referido lapso temporal.

Porém, é necessário deixar claro que não há um período fixo ou pré-determinado de tempo que seja apto a caracterizar o assédio moral em virtude da repetição da conduta. Mas sabe-se que geralmente, o lapso temporal geralmente acaba por ser relativamente longo, para que possa causar danos de real natureza, com reais desdobramentos.

\subsubsection{Finalidade}

O assédio moral possui como finalidade principal causar a exclusão do empregado agredido em seu ambiente laborativo. Isso se dá através da prática de condutas constrangedoras, humilhantes, vexatórias, maldosas, todas no intuito de ferir emocionalmente a vítima, diminuindoa perante o mercado de trabalho, tornando-a cada vez menos competitiva

\footnotetext{
${ }^{19}$ BARROS, Renato da Costa Lino de Goes. Assédio moral: análise sob a luz dos aspectos configurativos e probatórios deste fenômeno social. Revista de Direito do Trabalho. São Paulo, n.129, p.177, jan./mar. 2008.
} 
ou totalmente improdutiva. Busca-se levar o empregado ao isolamento, para que com isso se alcance os mais escusos objetivos.

O assédio moral é um meio indireto de se alcançar objetivos. Através dele, o agressor, que, por exemplo, seja um superior hierárquico, pode forçar o empregado a desistir do emprego e fazer com que ele peça demissão. Com isso, tal empregado abre mão de direitos trabalhistas, como a multa de $40 \%$ do FGTS e o direito ao saque do FGTS. Quando o assédio parte dos colegas de trabalho, muitos podem ser os motivos justificantes, como por exemplo, inveja pelo cargo ocupado pela vítima e a vontade do assediador de estar naquele cargo, vingança, competição desmedida, etc.

Patrícia Oliveira Lima Pessanha diz que a finalidade do assédio moral "em regra, visa drenar de tal forma a energia, o ânimo, a confiança, a estrutura psicológica do assediado, de forma a tornar a continuidade daquela relação de trabalho insuportável"20.

Realmente é isso o que se espera alcançar com o assédio moral. Quer-se que o ambiente de trabalho se torne tão insuportável a ponto de eliminar aquela pessoa daquele local.

\subsection{O DANO PSICOLÓGICO}

Apesar da grande discussão doutrinária, opta-se por não inserir a comprovação existência do dano psicológico como elemento caracterizador do assédio moral, mas sim como uma consequência lógica das condutas ilícitas reiteradas.

Candy Florêncio Thomé em postura semelhante com ao qual se compactua, explica:

Para que haja a configuração do assédio moral no âmbito das relações de emprego, faz necessário que tenha havido ato agressor, um dano á dignidade do trabalhador. Não se trata de necessidade de dano físico-psíquico, mas os atos devem causar uma

\footnotetext{
${ }^{20}$ PESSANHA, Patrícia Oliveira Lima. Assédio moral: conseqüências e formas de prevenção no ambiente empresarial. Disponível em: <http://www.webartigos.com/articles/28476/1/>. Acesso em: 20 mai. 2016.
} 
degradação das condições de trabalho, não havendo necessidade da prova direta do dano, uma vez que a mera existência de assédio moral já configura a conduta abusiva, e o dano moral é um dano in re ipsa. $^{21}$

Nesse mesmo sentido, manifesta-se Maria Aparecida Alkimin:

Para a reparação do dano moral, é imprescindível a prova dos fatos que dão causa ao dano moral, entretanto, é prescindível a prova da dor, sofrimento e perturbação interior causada pela conduta ilícita, pois a doutrina e a jurisprudência admitem a teoria do danun in re ipsa, para a qual o dano se prova por si mesmo, ou seja, provando o ilícito, dispensa-se a prova do prejuízo moral in concreto, pois ferir os direitos da personalidade e afetar o mais íntimo sentimento humano, é de difícil constatação. ${ }^{22}$

Através das lições das citadas autoras percebe-se que o dano moral é presumido, pois a conduta abusiva e degradante por si só já resta caracterizada a ilicitude dos atos, configurando o assédio moral.

Há quem pense ser o dano psicológico elementar para que o assédio moral se constitua como prática ilícita, pois não havendo o dano não haveria que se falar em assédio moral. Mas, em contrapartida, existem aqueles que entendem ser irrelevante a comprovada ocorrência do dano de caráter psicológico, pois acima de tudo, o assédio moral engloba atitudes que ferem direitos personalíssimos e fundamentais, de garantia constitucional, e por isso, por si só, sua prática já configura ato ilícito.

Argumenta-se também, que se for entendido que o dano à saúde mental da vítima é necessário para a configuração do assédio moral, pessoas mais equilibradas, com melhor estrutura emocional, ficariam desamparadas ao sofrerem as condutas do assédio, por pura e simples falta de requisitos caracterizadores.

${ }^{21}$ THOME, Candy Florencio. O assédio moral nas relações de emprego. Revista IOB Trabalhista e Previdenciária. Porto Alegre, n. 230, p. 31.

${ }^{22}$ ALKIMIN, Maria Aparecida. Assédio moral na relação de emprego. Curitiba: Juruá, 2005. p. 117. 
E o Direito não pode compactuar com isso. Não é pelo fato de uma pessoa reagir, internamente, diferente da outra que o assédio deva ou não ser tido como conduta ilícita. Deve-se enfocá-lo sobre a ótica dos direitos fundamentais e do princípio da dignidade da pessoa humana. E sendo assim, o assédio moral, por si só, já é prática ilícita, e independe de dano psicológico evidente e efetivo.

É notável que o dano psicológico está intrínseco às atitudes de assédio moral, mas não quer dizer que somente quando ele "se apresenta ao mundo", é que resta-se caracterizado. Tem-se que pensar que o assédio moral se materializa com as condutas reiteradas de terror psicológico, que são capazes de atentar contra a saúde mental da pessoa agredida, e não com o diagnóstico preciso de dano psicológico efetivo.

Deve-se entender que há o assédio com a presença da conduta assediosa repetitiva e prolongada, capaz de causar a degradação do sistema emocional do sujeito passivo, sendo, com isso, o dano psíquico, uma consequência do assédio moral e não um elemento caracterizador deste.

Por isso, é de suma importância perceber que o assédio moral configura-se em uma série de atitudes que ferem garantias e princípios fundamentais elencados na Constituição Federal de 1988. É uma prática ilícita que vai além da esfera pessoal da vítima, para atingir toda uma sociedade, na qual preceitos de máxima importância são deixados de lado para simplesmente satisfazer os interesses do agente.

\section{$4 \quad$ DA RESPONSABILIDADE CIVIL}

\subsection{INTRODUÇÃO}

O assédio moral no ambiente de trabalho é considerado prática ilícita e por isso cabe ao assediante/agressor a obrigação de indenizar a vítima/empregado pelos danos morais e materiais que lhe foram acarretados, bem como também nos casos de lucros cessantes, caso ocorram. Cumpre destacar que no tocante ao dano moral decorrente do assédio moral no ambiente laborativo, entende ser ele traduzido no que se chama de dano in re ipsa, ou seja, um dano que possui a sua ocorrência presumida com a simples prática das ações ilícitas, independente de efetiva com- 
provação, o que facilita um pouco para o empregado vitimizado, porém tal posição não encontra unanimidade.

Como a CLT, em seu art. $8^{\circ}$, parágrafo único, autoriza que o direito comum seja fonte subsidiária do Direito do Trabalho, nos casos em que não houver incompatibilidade com os seus princípios fundamentais, conclui-se que no campo do assédio moral, utilizam-se as normas de direito civil, no que diz respeito à responsabilidade por atos ilícitos, face a CLT não possuir disposições expressas sobre o assunto.

Nos casos de assédio moral, entra em cena, de modo geral, a responsabilidade civil subjetiva, regulamentada nas normas do direito comum. Para que ela fique demonstrada, deverão estar presentes os seguintes elementos: conduta, nexo causal, resultado, dolo ou culpa. Para este tipo de responsabilidade, é imprescindível que o agente aja pelo menos com culpa, porque se não, a responsabilidade dele não se consolida e com isso não há que se falar no dever de indenizar.

A responsabilidade civil subjetiva é um tipo de responsabilidade direta, na qual quem cometeu o ato ilícito é quem fica obrigado a reparar o dano, sem que constem intermediários ou responsáveis indiretos pelo dano.

Porém, após o advento do Código Civil de 2002, contemplou-se um novo tipo de responsabilidade civil, sendo chamada de objetiva. Nesta nova forma de responsabilidade, o elemento culpa é dispensável. O Código Civil elencou as situações em que a responsabilidade objetiva é cabível, demonstrando com isso, que ela realmente é forma excepcional de responsabilidade civil, permanecendo no Brasil a regra da responsabilidade civil subjetiva.

Neste diapasão, conforme a figura do sujeito ativo do assédio moral, surge determinado tipo de responsabilidade civil, mas em todas as suas vertentes, a ideia é que a vítima, ou seja, o empregado, seja ressarcido pelos danos morais e materiais que sofreu e que o assediador seja punido, demonstrando o caráter indenizatório da responsabilidade civil, como forma de coibir atos ilícitos e reparar os danos psicológicos auferidos pela vítima.

Contudo, a indenização não deve ser um meio de enriquecimento sem causa da vítima. Por isso, hoje em dia enfrenta-se imensa dificuldade no tocante a como quantificar os prejuízos e estabelecer um justo valor indenizatório a quem sofreu o dano moral. 
Em um de seus julgamentos, o Tribunal Superior do Trabalho afirmou:

A quantificação do valor do dano é tema polêmico na doutrina e jurisprudência ante a ausência de disciplina legal precisa, omissão decorrente, certamente, da própria natureza do dano, vez que, através de bens materiais, tenta-se ressarcir bens imateriais. Por essa razão, via de regra, apega-se a critérios objetivos para "quantificar o sofrimento" (...)

A dor física, o sofrimento, a humilhação, não são mensuráveis, daí a dificuldade em se fixar um valor que supostamente venha a 'ressarcir' o dano sofrido. $\mathrm{Na}$ verdade, a indenização por danos morais serve para educar quem praticou o ato ilícito e para diminuir o dano sofrido, mas com certeza de forma que não cause enriquecimento injusto do ofendido ou falência do ofensor. ${ }^{23}$

É necessário atentar para as novas tendências abrigadas aos pensamentos dos Tribunais brasileiros, que é a de não deixar que a responsabilidade civil esteja unicamente baseada na ideia da indenização dos prejuízos, indo muito mais além, ao ganhar um escopo repressivopunitivo, como o intuito de desestimular futuras ações reincidentes, ganhando assim um caráter eminentemente pedagógico.

\subsection{DA RESPONSABILIDADE CIVIL DOS ASSEDIANTES}

\subsubsection{A responsabilidade civil do superior hieráquico/empregador pela ótica da responsabilidade subjetiva}

\footnotetext{
23 Disponível em: http://aplicacao2.tst.jus.br/consultaunificada2/inteiroTeor.do, Acesso em: 27 mai. 2016.
} 
O superior hierárquico/empregador quando assume a postura de assediar moralmente seu subalterno, comete um ato ilícito, e conforme o art. 186 c.c 927 do Código Civil, ficando obrigado a reparar os danos causados.

A responsabilidade civil do empregador é subjetiva, ou seja, depende da prova do dolo ou da culpa para caracterização do ilícito e consequentemente para o surgimento do dever de indenizar.

Porém, provar dolo e culpa nem sempre é algo fácil de se realizar, sendo isso um ponto favorável ao empregador assediante, que acaba ficando encoberto no teor de tal dificuldade. E mais, a prova da culpa cabe à vítima, que nem sempre possui a mínima condição de tal realização, pois sofreu danos ao seu psicológico e desencadeou de várias doenças que a deixaram debilitada. Para facilitar um pouco à vítima, pelo menos no tocante ao dano moral, sendo ele considerado in re ipsa, sua comprovação torna-se menos complexa, pois ele torna-se presumido.

Provada a culpa ou o dolo, ou presumidos estes quanto pelo menos ao dano moral, surge para o empregador o dever de indenizar o assediado por todos os prejuízos por ele causados, de cunho material e moral.

Assim posicionou-se o Tribunal Regional do Trabalho da $15^{\mathrm{a}}$ região:

Dano moral. Transferência de setor. Inatividade forçada. Ausência de condições condignas de labor. Caracterização. Ficou comprovado nos autos que a reclamante foi transferida para setor, onde seus serviços eram desnecessários, ficando em situação de "inatividade forçada" e onde sequer lhe foram oferecidas condignas condições de trabalho, haja vista que não lhe foi destinada nem mesa nem cadeira para laborar. Essa conduta do empregador caracterizou assédio moral, porque a humilhação e constrangimento a que foi submetida a reclamante no desempenho de suas funções abalou sua autoestima, violando o princípio da dignidade como pessoa humana, adotado como fundamento de nossa república (art. $1^{\circ}$, iii e iv, da cf) e que consiste no limite intransponível ao poder diretivo empresarial. Em razão dessa conduta, o reclamado foi condenado ao pagamento de indenização por dano moral (grifo 
nosso). Recurso ordinário provido neste aspecto. 0065700-19.2009.5.15.0145 ro - recurso ordinário. ${ }^{24}$ $4^{\mathrm{a}}$ Região:

Com a mesma visão, julgou o Tribunal Regional do Trabalho da Acórdão - Processo 0106600-95.2008.5.04.0012
(RO) Relator: LUCIA EHRENBRINK

Data: 27/01/2010 Origem: $12^{\mathrm{a}}$ Vara do Trabalho de Porto Alegre

EMENTA: DANOS MORAIS. ASSÉDIO MORAL. Demonstrado pela prova oral colhida em audiência a prática de atos constrangedores e atentatórios à dignidade pessoal da trabalhadora no ambiente de trabalho, por parte de seu superior hierárquico, é devida a reparação dos danos morais que a conduta abusiva deu causa. Agrava-se o fato por ter se tornado de conhecimento generalizado no âmbito da empresa, expondo indevidamente a trabalhadora a comentários indesejáveis de outros funcionários. Quantum indenizatório mantido. (... $)^{25}$

A indenização surge como a forma encontrada para se compensar a vítima e tentar fazer com que ela retorne ao seu status quo ante. $\mathrm{O}$ caráter dessa indenização, como já foi dito, é eminentemente ressarcitório/compensatório. E vale a pena ressaltar, que o pagamento dessa indenização possui natureza jurídica de sanção devido à prática de atos ilícitos.

O dever indenizatório é uma forma de coibir abusos contra os trabalhadores, que no caso do assédio moral, vem a sua honra subjetiva

\footnotetext{
24 Disponível em: http://consulta.trt15.jus.br/consulta/owa/wPesquisaJurisprudencia, Acesso em : 25 jan. 2016.

${ }^{25}$ BRASIL. Tribunal Regional do Trabalho da $4^{\mathrm{a}}$ Região. Recurso Ordinário. Matéria Trabalhista. Danos morais e assédio moral. RO n. Disponível em: 010660095.2008.5.04.0012. Relatora: LUCIA EHRENBRINK. Porto Alegre. Data do Julgamento: $27 / 01 / 10$. Disponível em: <http://www.trt4.jus.br/portal/portal/trt4/consultas/jurisprudencia/acordaos>. Acesso em 15 mai. 2016.
} 
na lama, totalmente degradada em face de práticas tão escusas que ferem a dignidade da pessoa humana e atingem a sociedade como um todo.

\subsubsection{A responsabilidade civil dos colegas de trabalho pela ótica da responsabilidade objetiva}

Conforme o art. 932, inciso III c.c 933, do Código Civil, o empregador ou comitente é responsável pela reparação civil dos danos causados por seus empregados, serviçais e prepostos, no exercício do trabalho ou em função dele.

Com a análise do dispositivo supra citado, percebe-se que é o empregado que comete o ato ilícito, porém o empregador, nesta linha de raciocínio, é quem responderá pelos danos ocasionados e deverá indenizar a eventual vítima. Com isso, consagra-se a responsabilidade civil objetiva do empregador.

Como já foi dito, na responsabilidade civil objetiva não se precede à discussão de culpa, surgindo o dever de reparar o dano independente desta. No caso do empregador, como ele é responsável por seus empregados, por tal vertente, é ele quem deverá ressarcir os danos auferidos pelas vítimas, tendo como única defesa, discutir que o seu empregado não teve culpa pelo evento danos. Discute-se a culpa do empregado como forma de defesa para que o empregador se livre do dever de indenizar, já que este está embutido na responsabilidade civil que o norteia.

No caso do assédio moral, quando é um empregado, colega de trabalho que comete práticas assediosas contra outro colega, caso este ingresse em juízo, pela tese da responsabilidade objetiva, é a empresa que ocupará o pólo passivo da relação, face a regra do art. 932 do código Civil. Nesta demanda, a vítima não precisa provar a culpa, pois esta já é presumida por força de lei.

Havendo condenação em danos morais, a empresa deverá pagar o valor contido na sentença e somente depois, com base no art. 934, do Código Civil, exercer o direito de regresso que a Lei lhe confere contra o verdadeiro agressor.

Porém, convém ressaltar que muitos indagam não ser aplicada a teoria da responsabilidade objetiva, devendo a empresa ser acionada em conjunto com o empregado agressor, formando um litisconsórcio passivo, 
o que demonstra que no campo do assédio moral há margens para muitas discussões.

\section{CONSIDERAÇÕES FINAIS}

Como se percebe, o assédio moral caracteriza-se por ser ato ilícito que gera para o assediante o dever de reparar os danos sofridos pela vítima, que no presente artigo foi considerada como o empregado, recaindo sobre o assunto, as regras referentes ao instituto da responsabilidade civil, reguladas no direito comum. Tais danos podem ser das mais diversas espécies: psicológico, moral e até mesmo material.

O que se busca com a indenização, é minimizar os danos acarretados à vítima e apresentar ao agressor uma punição, para que este não cometa, novamente, a conduta ilícita que estava acostumado a praticar.

No assédio moral, o dano moral pode ser presumido, sendo considerado in re ipsa; o material deverá ser comprovado e o psicológico poderá ou não ocorrer, porém não sendo este elemento caracterizador dessa espécie de assédio ora debatido. Porém, em todos os casos, a indenização se fará presente por ser medida de cunho compensatório, punitivo e sócio-educativo.

\section{REFERÊNCIAS BIBLIOGRÁFICAS}

AGUIAR, André Luiz Souza. Assédio moral: o direito à indenização pelos maus tratos e humilhações sofridos no ambiente de trabalho. São Paulo: LTR, 2005.

ALKIMIN, Maria Aparecida. Assédio moral na relação de emprego. Curitiba: Juruá, 2005.

Assédio moral: sujeitos, danos à saúde e legislação. http://psicologiaetrabalho.blogspot.com/2007/08/assdio-moralsujeitos-danos-sade-e.html. Acesso em 9 jan. 2016.

Assédio moral no trabalho: e o que é assédio moral no trabalho? Disponível em: http://www.assediomoral.org/spip.php?article1. Acesso em:16 jan. 2016.

BARROS, Renato da Costa Lino de Goes. Assédio moral: análise sob a luz dos aspectos configurativos e probatórios deste fenômeno 
social. Revista de Direito do Trabalho. São Paulo, n.129. p.177. jan/mar 2008.

BRASIL. Tribunal Regional do Trabalho da $15^{\mathrm{a}}$ região. Indenização. matéria trabalhista. assédio moral. Ofensa à honra, à imagem e à dignidade do trabalhador. Decisão no 027971/2010. Relator: José Antonio Pancotti. Disponível em: http://consulta.trt15.jus.br/consulta/owa/wPesquisaJurisprude ncia. Acesso em: 16 mai. 2016.

CAIRO JÚNIOR. José. Curso de direito do trabalho: direito individual e coletivo do trabalho. 3.ed. Salvador: Jus Podivm, 2009.

GÓIS, Luiz Marcelo Figueiras de. Assédio moral: a nova ameaça à integridade do ambiente de trabalho. Revista IOB Trabalhista e Previdenciária. Porto Alegre, n. 243, p.88, Set./09.

GUEDES, Márcia Novaes. Terror psicológico no trabalho. 2.ed. São Paulo: LTr, 2005.

HIRIGOYEN, Marie-France. Le harcèlement moral: la violence perverse du quotidian. Paris: Editions Le Livre de Ponche, 2000.

MARTINS. Sérgio Pinto. Direito do trabalho. 24.ed. São Paulo: Atlas, 2008.

NASCIMENTO, Sônia Maria Mascaro. O assédio moral no ambiente do trabalho.

http://jus2.uol.com.br/doutrina/texto.asp?id=5433. Acesso em: 9/05/2016.

PAMPLONA FILHO, Rodolfo. Noções conceituais sobre o assédio moral na relação de emprego. Revista de Direito do Trabalho. São Paulo, n. 125, ano 33, p. 193-194, Jan./Mar.2007.

- Noções conceituais sobre assédio moral nas relações de emprego. Disponível em: www.anamatra.org.br/opiniao/artigos/ler_artigos.cfm?cod_conteud o+7987\&descriçao=Artigos. Acesso em: 13/05/2016.

PEDUZZI, Maria Cristina Irigoyen. Assédio moral. Revista do Tribunal Superior do Trabalho. Rio de Janeiro, n. 2, v. 73, p.25, abr./jun 2007.

PESSANHA, Patrícia Oliveira Lima. Assédio moral: conseqüências e formas de prevenção no ambiente empresarial. Disponível em: http://www.webartigos.com/articles/28476/1/. Acesso em: 20 mai. 2016,

THOME, Candy Florencio. $O$ assédio moral nas relações de emprego. São Paulo: LTR, 2008. 
- O assédio moral nas relações de emprego. Revista IOB Trabalhista e Previdenciária. Porto Alegre, n. 230, p. 31, Ago/2008 
